\title{
INEQUALITY AND INTERNATIONAL TRADE: THE ROLE OF SKILL-BIASED TECHNOLOGY AND SEARCH FRICTIONS
}

\author{
MORITZ RITTER \\ Temple University
}

I embed a competitive search model of the labor market into a small open economy model with heterogeneous firms and workers. Search frictions generate equilibrium unemployment and income inequality between identical workers, in addition to income differences between skill groups. A quantitative evaluation of the U.S. trade experience suggests that the effect of the increase in goods trade since 1980 may have contributed to the increase in the college premium, but not to the increase in residual inequality.

Keywords: Competitive Search, Income Inequality, International Trade, Skill-Biased Technology

\section{INTRODUCTION}

The past three decades have seen a marked rise in income inequality and a boom in international trade, in developed and developing countries alike [see Goldberg and Pavcnik (2007) for a survey documenting these facts]. Seemingly unrelated to this, a well-documented stylized fact in international economics is that exporting firms are typically more productive and employ higher-skilled workers than nonexporters [e.g., Bernard et al. (2007)]. Yet only recently has research on the distributional effects of globalization focused on the link between firm heterogeneity and the reallocation of workers within an industry. This literature stresses the role of the interaction of skill-biased technology and firm heterogeneity in the effect of increased trade on income inequality: in such an environment, trade liberalization causes a reallocation of workers within an industry toward the most productive (exporting) firms and increases the skill premium [e.g., Yeaple (2005); Burstein and Vogel (2012)].

In this paper, I combine this reallocation mechanism with a competitive search model of the labor market. As in Kaas and Kircher (2015), firms are large in the sense that they are not restricted to hiring only one worker (as in a standard search model) and they commit to long-term contracts. This allows the incorporation of 
a competitive search framework into a small open economy model featuring monopolistic competitive firms with heterogeneous productivity, as in Melitz (2003). Firms produce differentiated varieties using a skill-biased technology (in that larger, more productive firms employ relatively more high-skilled workers). More productive firms have a stronger incentive to fill their vacancies and post them in submarkets with a high vacancy filling rate. However, to compensate workers for the correspondingly lower job-finding rate, these submarkets offer more lucrative contracts-differences in firm productivity thus translate into residual wage inequality.

I calibrate the model to the U.S. economy and simulate the effect of the increase in trade between 1980 and 2005, a period during which inequality rose markedly. After the trade shock, only the most productive firms within an industry begin to export because of the fixed cost incurred for exporting. Because these firms have a higher skill intensity than nonexporters, a trade shock increases the relative demand for high-skilled workers in that industry. In addition, the manufacturing industries that see the largest increase in exports are also the ones that employ a relatively more highly skilled labor force. Hence any reallocation of workers toward exporting industries further increases the demand for high-skilled workers. With these effects taken together, the model predicts a 3.8 log point increase in the skill premium and a 2 percentage point decrease in the unemployment rate among high-skilled workers.

Because the least productive firms are reducing their labor forces and the most productive firms are increasing theirs, the distribution of worker-firm matches is tighter, which decreases the 90-10 residual wage gap. However, computing the Theil index separately for each skill group shows that the within-group dispersion decreases for high-skilled and increases for low-skilled workers; high-skilled workers are now less dispersed across firm productivities, whereas low-skilled are more dispersed.

This paper is related to an active literature on trade and inequality. ${ }^{1}$ In particular, the model in this paper is close to other work combining search models of the labor market with trade models in order to study labor market implications of international trade. Davidson et al. (2008a, 2008b) study the effect of offshoring on the skill premium in a random search model with skill-biased technology and Ritter (in press) uses a directed search model with a skill-biased technology to study the effect of trade on both the skill premium and residual inequality. ${ }^{2}$ Differently from the current paper, these papers follow the one-worker-one-firm modeling approach, as is common in search models. Consequently, they do not combine the search model of the labor market with the standard monopolistic-competitive model with heterogeneous firms (dominant in much of the international trade literature), which is a drawback for any quantitative analysis.

As in this paper, Helpman et al. (2010) and Cosar et al. (in press) introduce heterogeneous firms employing multiple workers into a search model. ${ }^{3}$ In these models, firms are randomly matched with ex ante identical workers and so they do not address the effect of trade on the skill premium. The mechanism by which 
within-group inequality is generated in Helpman et al. (2010) greatly differs from the one in this paper. In their model, workers receive unobserved productivity shocks and more productive firms screen workers more intensively, giving rise to within-group inequality. The competitive search framework used in the present paper generates income inequality directly among otherwise identical workers through the labor market. Cosar et al. (in press) generate within-group inequality through rent-sharing and find that although dispersion of firm level wages increases, the polarization of employment at more productive firms undoes most of the increase in dispersion. This mirrors the finding in the present paper, where within-group inequality may increase or decrease, depending on changes in the worker distribution across firms. Conversely, in Helpman et al. (2010), withingroup inequality is unambiguously increasing for small increases in the number of firms exporting. ${ }^{4}$

A different, complementary approach is taken by Yeaple (2005), Costinot and Vogel (2010), and Sampson (2014), who study the effect of trade on inequality using assignment models. Whereas Costinot and Vogel (2010) abstract from firms, Yeaple (2005) and Sampson (2014) study the assignment of heterogeneous workers across heterogeneous firms and find that following a trade reform, the increase of demand for the most productive workers from the most productive firms increases the skill premium, a channel operating in this paper as well.

There are also a large number of recent papers studying the effect of trade on labor market outcomes with frictionless labor markets. The effect of trade on the skill premium is studied in Burstein and Vogel (2012), who also stress the interplay between skill-biased technology and the Stolper-Samuelson acrossindustry effect. Harrigan and Reshef (in press) introduce worker heterogeneity into a Melitz (2003) model and Epifani and Gancia (2008) introduce worker heterogeneity into a Krugman (1979) model. These models, however, abstract from within-group inequality and unemployment. Within-group inequality is studied by Egger and Kreickemeier (2009) in a fair wage model with homogeneous workers. Davis and Harrigan (2011) study the effect of trade on unemployment in a efficiency wage model. Last, there are, of course, alternative explanations for the increase in inequality for the past decades, most prominently skill-biased technological change [e.g., Goldin and Katz (2007) and Acemoglu and Autor (2011)].

\section{MODEL}

I consider a small open economy in a stationary equilibrium. Time is discrete and lasts forever. There are large numbers of workers and firms in the economy; the mass of workers is normalized to one and the mass of firms is determined in equilibrium. Workers can be of two types, high-skilled $(h)$ and low-skilled $(u)$, and the fraction of high-skilled workers is given by $\bar{h}$. Workers are infinitely lived and risk-neutral and discount the future at a rate $\beta$. They are endowed with one unit of productive time each period. 
Firms are large relative to workers, so each firm employs multiple workers. Firms become active by paying a fixed entry cost and remain active until they are hit with an exogenous shutdown shock. After entering, firms learn their productivity and then seek to recruit workers. Recruiting takes place in a frictional labor market, described in detail in the Subsection 2.1. Workers and firms remain matched until the firm is shut down or the match is exogenously separated.

The timing within a period is as follows: First, potential entrants pay the entry cost and their productivity level is revealed. At the same time, for existing firms, the separation shock (from a worker) and exit shock are realized. Second, firms make their recruitment decisions. Third, firms and workers are matched. Unemployed workers will always be able to search, even if they separated in the same period. Last, production takes place. Newly formed matches are not productive in the current period.

\subsection{The Labor Market}

The model of the labor market is similar to the competitive search model with large firms in Kaas and Kircher (2015). Firms and workers match in a frictional labor market, which is segregated into many submarkets. Firms recruit workers by posting vacancies; all firms post their vacancies into the same set of submarkets. Workers can freely choose which submarket to visit, irrespective of their employment histories. In a submarket, vacancies and workers are matched according to a constant-returns matching function, so the matching rates for vacancies and workers depend only on the unemployed-vacancy ratio in that submarket, $\theta$. Let $m(\theta)$ denote the arrival rate of workers at vacancies; i.e., firms that post $V$ vacancies will hire $m(\theta) V$ workers. Conversely, the job-finding probability for a worker is $m(\theta) / \theta$. The function $m(\theta)$ satisfies $m^{\prime}(\theta)>0, m^{\prime \prime}(\theta)<0$, and $m(0)=0$.

A vacancy consists of a wage offer $w$; all firms within a submarket post the same wage. Consequently, submarkets are characterized by the contract offer $w$ and unemployment-vacancy ratio $\theta$. The wage remains constant for the duration of the match; i.e., firms offer long-term contracts and are committed to paying the posted flat wage until the match is separated. ${ }^{5}$ These long-term contracts imply that there potentially is wage dispersion for identical workers within a firm, depending on the timing of their hires.

It is costly for a firm to post vacancies. The cost of posting a vacancy depends on the number of vacancies the firm posts for each type of worker and the employment stock of the firm. Let $V_{u}$ and $V_{h}$ denote the numbers of vacancies for low- and highskilled workers, respectively. The cost for a firm to post these vacancies is given by $C\left(V_{u}, V_{h}, u, h\right) ; C$ is monotone increasing and convex in $V$ (i.e., the marginal cost of posting a vacancy is increasing in the number of vacancies posted) and weakly decreasing in the firm's employment stock. This captures various recruiting and adjustment cost that are increasing in the number of new hires.

Workers observe all posted vacancies and then decide which submarket to enter. Workers who are matched with the firm start producing in the next period 
and unmatched workers receive an unemployment benefit $b$. Matched workers and firms remain together until either the firm exits or their match is broken up. Firms exit at a rate $\delta$ and existing matches break up at a rate $\gamma$. Thus, an employed worker becomes unemployed at rate $\pi=\delta+(1-\delta) \gamma$.

\subsection{The Worker's Problem}

Consider a worker employed at wage $w$. She faces a probability $\pi$ of loosing her current match and returning to the pool of unemployed workers. Let $\mathcal{J}(w)$ denote the value of being employed at wage $w$ and let $\mathcal{U}$ denote the time-invariant value of searching (recall that newly separated workers can search immediately). The flow payoff of search is given by $(1-\beta) \mathcal{U}$ and the surplus value from being employed at the present wage $w$ is given by

$$
\mathcal{J}(w)-\mathcal{U}=\frac{w-(1-\beta) \mathcal{U}}{1-\beta(1-\pi)}
$$

Unemployed workers observe the wages posted and form expectations about the corresponding market tightness in each submarket. Because any match being created this period only becomes productive in the following period, the value of entering a submarket with wage offer $w$ and tightness $\theta$ is given by

$$
\begin{aligned}
\mathcal{W}(w, \theta) & =b+\beta \frac{m(\theta)}{\theta}(1-\delta) \mathcal{J}(w)+\beta\left[1-\frac{m(\theta)}{\theta}+\frac{m(\theta)}{\theta} \delta\right] \mathcal{U} \\
& =b+\beta \mathcal{U}+\beta \frac{m(\theta)}{\theta}(1-\delta)(\mathcal{J}(w)-\mathcal{U}) .
\end{aligned}
$$

That is, the value of entering a submarket consists of the continuation value of search plus the product of the surplus value of employment offered by firms in that submarket and the probability of being hired in that submarket (and the job not immediately being terminated).

Any submarket that attracts a positive number of workers must offer the same value of search. To see this, consider two submarkets with identical market tightness, i.e., identical job-finding probabilities. If the contract offered in the first submarket promises a higher surplus than the one promised in the second submarket, the first submarket will offer a higher expected value of search. Consequently, more workers will enter the first submarket, which will increase the market tightness and lowers the job-finding rate until both submarkets offer the same value of search. Therefore, at equilibrium, all submarkets must satisfy

$$
\mathcal{W}(w, \theta) \leq \mathcal{U}, \theta \geq 0 \text {, with c.s. }
$$

Because all active submarkets must offer the same value of search at equilibrium, workers face a trade-off when deciding which submarket to enter: more lucrative contracts are more difficult to find. Using (3) and substituting (1) into (2) shows 
the trade-off between the job-finding rate and the wage paid:

$$
w=(1-\beta) \mathcal{U}+\frac{\theta}{m(\theta)} \frac{[1-\beta(1-\pi)]}{(1-\delta)} \overline{\mathcal{S}},
$$

where $\overline{\mathcal{S}}=((1-\beta) \mathcal{U}-b) / \beta$; submarkets with a high wage offer must have a low job-finding probability.

\subsection{The Goods Market}

The economy consists of $J$ sectors (industries), each producing a distinct good, $Q_{j}$. Each industry produces a composite good consisting of a continuum of many differentiated varieties; each firm in industry $j$ produces one tradable variety $k \in K_{j}$. The composite good of each industry is given by the CES index:

$$
Q_{j}=\left(\int_{k \in K_{j}} y_{j, k}^{\varphi} d k\right)^{1 / \varphi},
$$

where $y_{j, k}$ denotes the quantity of variety $k$ in industry $j$ and $\varphi \in(0,1)$ governs the elasticity of substitution between the varieties.

The final consumption good is an aggregate of the composite goods:

$$
\mathbf{Q}=\prod_{j=1}^{J} Q_{j}^{\zeta_{j}}
$$

with $\sum_{j=1}^{J} \zeta_{j}=1$; i.e., $\zeta_{j}$ is the fraction of aggregate income spent on good $j$. Let $P_{j}$ denote the ideal price index for industry $j$ :

$$
P_{j}=\left(\int_{k \in K_{j}} p_{j, k}^{\frac{-\varphi}{1-\varphi}}\right)^{\frac{\varphi-1}{\varphi}}
$$

Utility maximization implies the following demand function for each variety of the differentiated good $j$ :

$$
y_{j, k}=A_{j} p_{j, k}^{\frac{-1}{1-\varphi}}
$$

where $A_{j}=\zeta_{j} \mathbf{Y}\left(P_{j}\right)^{\varphi /(1-\varphi)}$ is a demand shifter that each firm takes as given and $\mathbf{Y}$ denotes aggregate income.

\subsection{The Firm's Problem}

An industry is modeled similarly to Melitz (2003), amended by the frictional labor market described in the preceding. At the beginning of the period, a potential firm can enter by paying a fixed cost $f_{e}$ in units of the numeraire good (a service good, described in Section 2.5). After entering, the firm draws its productivity $s$ from 
some distribution $G(s)$. The productivity level remains constant for the life of the firm. Active firms are subject to an exit shock, $\delta$.

Firms produce output according to the following production function: ${ }^{6}$

$$
y(s, u, h)=\bar{a}\left[\lambda_{u} u^{\rho}+\left(1-\lambda_{u}\right)(s h)^{\rho}\right]^{1 / \rho},
$$

where $u$ and $h$ denote the number of low- and high-skilled workers employed, $\rho \in(0,1)$ governs the degree of substitutability between high- and low-skilled workers, $\lambda_{u}$ is a parameter governing the skill intensity of the industry, and $\bar{a}$ is an industry-specific productivity parameter. Furthermore, $\rho<\varphi$; i.e., workers of different skill levels are more complementary (or less substitutable) than varieties within the industry. ${ }^{7}$

Firms have access to the differentiated goods market in another country (world market). However, in order to export, the firm has to pay a per-period fixed cost, $f_{x}$. Also, there is a variable cost (iceberg cost): in order to sell one unit in the world market, the firm has to ship $\tau_{x}>1$ units. Let the two countries be named $\mathrm{H}$ (home) and $\mathrm{X}$ (export) and the quantities sold of each variety $q_{\mathrm{H}}$ and $q_{\mathrm{X}}$, respectively. Profit maximization for an exporting firm requires the firm to equalize the marginal revenue across markets. Taking into account the iceberg cost and the exchange rate, $e$, this implies the following relative quantities sold by an exporting firm:

$$
\frac{q_{\mathrm{H}}}{q_{\mathrm{X}}}=\left(\frac{A_{\mathrm{X}}}{A_{\mathrm{H}}}\right) \tau_{x}^{\frac{-\varphi}{1-\varphi}} e^{\frac{-1}{1-\varphi}} .
$$

Thus, the firm's total revenue is

$$
\mathbf{R}=\left(A_{\mathrm{H}}+\mathbf{I}_{x} \tau_{x}^{\frac{-\varphi}{1-\varphi}} e^{\frac{1}{1-\varphi}} A_{\mathrm{X}}\right)^{1-\varphi} y^{\varphi},
$$

where $\mathbf{I}_{x}$ is an indicator variable that equals one if the firm decides to export and zero otherwise.

After the exit and separation shocks are realized and the new firms have entered, firms make their vacancy posting and export decisions. When making the vacancy posting decision, the firm takes the equilibrium value of search as given; i.e., the firm realizes that any submarket must satisfy (3). Let $W_{u}$ and $W_{h}$ denote the wage bills committed to low- and high-skilled workers, respectively, and $\hat{x}$ the next period's value of any variable $x$. The Bellman equation for an active firm is given by

$$
\begin{aligned}
\mathcal{V}\left(s, u, h, W_{u}, W_{\mathrm{H}}\right)= & \max _{\left(\mathbf{I}_{x}, w_{u}, w_{h}, \theta_{u}, \theta_{h}, V_{u}, V_{h}\right)} A\left(\mathbf{I}_{x}\right) \bar{a}\left[\lambda_{u} u^{\rho}+\left(1-\lambda_{u}\right)(s h)^{\rho}\right]^{\frac{\varphi}{\rho}} \\
& -W_{u}-W_{h}-C\left(V_{u}, V_{h}, u, h\right)-\mathbf{I}_{x} f_{x} \\
& +\beta(1-\delta) \mathcal{V}\left(\hat{s}, \hat{u}, \hat{h}, \hat{W}_{u}, \hat{W}_{\mathrm{H}}\right),
\end{aligned}
$$


subject to

$$
\begin{aligned}
\hat{u} & =\left(1-\gamma_{u}\right) u+m\left(\theta_{u}\right) V_{u}, \\
\hat{h} & =\left(1-\gamma_{\mathrm{H}}\right) h+m\left(\theta_{h}\right) V_{h}, \\
\hat{W}_{i} & =\left(1-\gamma_{i}\right) W_{i}+m\left(\theta_{i}\right) V_{i} w_{i}, \quad i=u, h \\
V_{i} & \geq 0, \quad i=u, h, \\
w_{i} & =(1-\beta) \mathcal{U}_{i}+\frac{\theta_{i}}{m\left(\theta_{i}\right)} \frac{[1-\beta(1-\pi)]}{(1-\delta)} \overline{\mathcal{S}}_{i}, \quad \theta_{i}>0, \quad i=u, h,
\end{aligned}
$$

where $A\left(\mathbf{I}_{x}\right)=\left(A_{\mathrm{H}}+\mathbf{I}_{x} \tau^{-\varphi /(1-\varphi)} e^{-1 /(1-\varphi)} A_{\mathrm{X}}\right)^{1-\varphi}$.

The set of constraints can be reduced by substituting the constraint on the wages offered, (10), into the law of motion for the wage bill, (8). The resulting first-order conditions lead to

$$
\begin{gathered}
C_{V_{i}} \geq \beta \overline{\mathcal{S}}_{i} \frac{m\left(\theta_{i}\right)-\theta_{i} m^{\prime}\left(\theta_{i}\right)}{m^{\prime}\left(\theta_{i}\right)}, \quad V_{i} \geq 0, \quad i=u, h, \\
A\left(\mathbf{I}_{x}\right) \hat{B}_{i}-\hat{C}_{i}-(1-\beta) \mathcal{U}_{i}=\frac{\overline{\mathcal{S}}_{i}}{1-\delta}\left[\frac{1}{m^{\prime}\left(\theta_{i}\right)}-\frac{\beta(1-\pi)}{m^{\prime}\left(\hat{\theta}_{i}\right)}\right],
\end{gathered}
$$

where $\hat{B}_{i}=\frac{\partial \bar{a}\left[\lambda_{u} u^{\rho}+\left(1-\lambda_{u}\right)(s h)^{\rho}\right]^{\varphi / \rho}}{\partial i}, i=\hat{u}, \hat{h}$.

The first equation describes the optimal trade-off between the number of vacancies posted and the market tightness. The firm can increase hiring either by increasing the yield per vacancy or by posting more vacancies. Increasing the yield per vacancy is costly because a high vacancy-filling rate for the firm implies a low job-finding rate for the workers. To offer the equilibrium value of search, the posted contract must promise high future wages for the hired worker. On the other hand, an increase in vacancies has a direct cost, $C_{V}$.

The second equation describes the evolution of the firm's hiring plan. The expression on the left-hand side is the net marginal revenue of an extra hire. If the marginal revenue is high next period, the yield per vacancy is high today. (Recall that a worker hired today will start producing tomorrow.) Because a high yield implies that the offered wage is also high, (12) states that firms that have high marginal revenue will grow quickly and pay higher wages.

Also note that all hiring decisions are independent of the firm's total payroll. From the viewpoint of the firm, total payroll is sunk because of commitment to the promised payments. As a consequence, posting wages (or contracts) overcomes the problem of overhiring in search models using the Stole-Zwiebel bargaining solution because the contracts of existing workers are unaffected by new hires. ${ }^{8}$

There is no uncertainty for firms after they enter; each firm of type $s$ follows a deterministic employment path. Therefore, the firm's state space can be reduced to productivity and age; age is a sufficient statistic to infer a firm's employment 
stock and wage bill, conditional on its productivity. Let the recruitment policy functions of firm $s$ at age $a$ be denoted as $g^{\theta}(s, a)$ and $g^{V}(s, a)$. The employment level of each firm of type $s$ and age $a \geq 1$ is given by

$$
\begin{aligned}
& u(s, a)=\sum_{t=0}^{a-1} g^{V_{u}}(s, t) m\left(g^{\theta_{u}}(s, t)\right)(1-\gamma)^{a-t-1}, \\
& h(s, a)=\sum_{t=0}^{a-1} g^{V_{h}}(s, t) m\left(g^{\theta_{h}}(s, t)\right)(1-\gamma)^{a-t-1} ;
\end{aligned}
$$

and $u(s, 0)=h(s, 0)=0$ is the initial employment level.

A firm begins exporting if the increase in revenue exceeds the fixed cost of accessing the world market. This depends on the firm's employment stock and productivity level:

$$
\mathbf{I}_{x}(s, u, h)=\left\{\begin{array}{cc}
0 & {\left[\left(A_{\mathrm{H}}+\tau^{\frac{-\varphi}{1-\varphi}} e^{\frac{-1}{1-\varphi}} A_{\mathrm{X}}\right)^{1-\varphi}-A_{\mathrm{H}}^{1-\varphi}\right] y^{\varphi}<f_{x}} \\
1 & \text { otherwise. }
\end{array}\right.
$$

Because $y$ is monotone increasing in $s, u$, and $h$, it follows from (15) that exporting firms are larger and more productive than nonexporters, consistent with empirical findings. Note that the decision to start exporting this period does not affect this period's hiring decision, but rather the previous period's. It follows from (12) that a firm increases its recruiting efforts if the next period's marginal revenue is high. This implies that, in anticipation of beginning to export tomorrow, the firm increases its hiring efforts today. This is consistent with recent empirical evidence that finds that firms typically start growing before they start exporting [e.g., Molina and Muendler (2013)].

\subsection{Service Firms}

Creating new firms, recruiting new workers, and exporting are costly. I assume that these costs take the form of services that are produced by a large number of service firms. Each of these firms operates a linear production technology that converts one unit of unskilled labor into one unit of services. These services are exclusively used to create goods-producing firms $\left(f^{e}\right)$, to enable exporting $\left(f^{x}\right)$, and to recruit workers in the frictional labor market $(C(\cdot))$. Service firms operate in a perfectly competitive market and are not subject to search frictions; they hire their labor in a perfectly competitive spot market each period. Because unskilled workers have the option to work for a service firm, their flow value of search in the frictional labor market is equal to the wage paid by service firms, which can be normalized to one and is the numeraire in the economy. 


\subsection{Equilibrium}

At equilibrium, entering firms must make zero expected profits; i.e.,

$$
f_{e}=\int_{s} \max \{\mathcal{V}(s, 0,0,0,0) ; 0\} d G(s) .
$$

Let $N_{0}(j)$ denote the number of newly entering firms that satisfies (16) for each industry $j$. Because firms only exit exogenously after the first period, the stationary distribution of firms over productivity and age is

$$
f(s, a)=(1-\delta)^{a} N_{0} g^{e}(s) d G(s) .
$$

As discussed earlier, a firm's employment path is deterministic and age and productivity are a sufficient statistic to infer the firm's remaining state variables. The distribution of firms over productivities and employment levels, $f(s, u, h)$, can be inferred from (13) and (14) in combination with (17). Therefore, (17) is the aggregate state variable of the economy.

The following gives the definition of the equilibrium for this economy; the details describing how to compute the equilibrium can be found in the Appendix.

DEFINITION 1. A stationary competitive search equilibrium for the small open economy consists of value functions $\left\{\mathcal{W}_{i}(w, s), \mathcal{U}_{i}\right\}_{i=u, h}$ for workers, value functions $\mathcal{V}\left(s, u, h, W_{u}, W_{\mathrm{H}}\right)$ and associated policy functions $g^{V_{u}}(s, a), g^{V_{h}}(s, a), g^{\theta_{u}}(s, a), g^{\theta_{h}}(s, a), g^{e}(s), \mathbf{I}_{x}(s, a)$ for firms, an invariant distribution of firms $f(s, a)$, a mass of entering firms $N_{0}(j)$, an aggregate income $\mathbf{Y}$, a price index for each industry $P(j)$, and an exchange rate $e$, such that

1. Workers' search decisions maximize their utility, i.e., (3) holds.

2. The firms' policy functions solve (5).

3. The free entry condition, (16), holds.

4. The aggregate resource constraint holds.

5. Markets clear.

6. Trade is balanced.

7. The distribution of firms is time-invariant.

\section{TRADE AND INEQUALITY}

In the model, a trade reform induces a reallocation of workers toward exporting firms, which are more productive and hence have a higher skill intensity. Although it is obvious that exporting firms will hire more workers, the extent to which the trade reform will increase the relative demand for skilled workers (and hence inequality) depends on the relative skill intensity of exporting firms. Industries differ in their skill intensity and not all industries export equally, so a trade liberalization also induces some across-industry reallocation of workers toward the comparatively advantaged industries. Differently from the within-industry reallocation, the across-industry allocation might increase or decrease the relative demand 
for skilled workers, depending on the relative skill intensity of the comparative advantage industries.

To shed some light on the relative importance of these two channels, this section explores some of the features of this model through a quantitative assessment of the U.S. trade experience. I first calibrate the model to capture key labor market aspects of the U.S. manufacturing sector in 1980. I then introduce a trade shock that matches the increase in trade in manufacturing between 1980 and 2005. Last, I conduct a counterfactual experiment in which U.S. exports are relatively more low-skill intensive than observed in the data.

\subsection{Parameterization}

The model period is one year, as the focus is a steady state analysis. Accordingly, I set the discount factor to $\beta=0.96$. The economy consists of two industries, representing a typical high- and a typical low-skill industry. Using data from the 1980 U.S. Census, I compute the educational compositions of the 82 manufacturing industries identified in the Census. I identify workers with some or completed college eduction as high-skilled $(h)$ and high-school graduates and dropouts as low-skilled $(u)$. According to this classification, in 1980, 27.5\% of workers in manufacturing were high-skilled. Industries which have a larger than average share of workers with at least some college education are labeled highskill-intensive $(\mathrm{H})$ and the remaining industries are labeled low-skill-intensive (L).

As a group, the $\mathrm{H}$-industries have slightly greater employment, $51.4 \%$ of total manufacturing employment in 1980 . On average, $34.9 \%$ of all workers in $\mathrm{H}$-industries are high-skilled, compared with $18.8 \%$ in L-industries. The overall skill premium for high-skilled workers was $33.8 \%$ in 1980 . Between 1980 and 2005, exports as a fraction of sales increased from $14.6 \%$ to $20.3 \%$ for $\mathrm{H}$-industries and from $6.3 \%$ to $8.9 \%$ for L-industries. Over the same time period, imports increased from $11.7 \%$ to $31.7 \%$ and $8.2 \%$ to $24.1 \%$ of total sales, respectively. ${ }^{9}$

I choose $\bar{a}$ and $\lambda_{u}$ to match the employment distribution and the skill premium. The elasticity of substitution between skilled and unskilled labor is set to 1.33, in line with values reported by Katz and Murphy (1992) and Krusell et al. (2000). The productivity distribution is exponential with parameter $\lambda=1$ and the cost of entry is normalized to $f^{e}=1$.

The elasticity of substitution between different varieties, governed by $\varphi$, is set to $4 .{ }^{10}$ The expenditure shares $\zeta_{j}$ are selected to match the relative sizes of the $\mathrm{H}$ and $\mathrm{L}$ industries in terms of value added. The foreign demand shifters, $A_{X, j}$, are set to match the exports-to-sales ratio for each industry group and the foreign relative price to match the relative size of exports (the level of exports is lower than in the data because of balanced trade). ${ }^{11}$ Last, the fixed cost of exports, $f^{x}$, is set to have $17.6 \%$ of all plants exporting [Bernard et al. (2002)]. 
Firms exit at a rate $\delta=0.1$ and low- and high-skilled workers separate at rates $\gamma_{u}=0.15$ and $\gamma_{h}=0.1$, respectively, implying an average tenure at the time of separation of 6.67 years for low-skilled workers and 10 years for high-skilled workers. The matching function is given by

$$
M(U, V)=\frac{U V}{\left(U^{\alpha}+V^{\alpha}\right)^{1 / \alpha}},
$$

with $\alpha=1.27$ [den Haan et al. (2000)]. The cost function for posting vacancies follows the specification used in Cosar et al. (in press) with full separability between the two skill groups in hiring:

$$
C\left(V_{h}, V_{u}, h, u\right)=c\left(V_{h}^{\eta_{1}} h^{\eta_{2}}+V_{u}^{\eta_{1}} u^{\eta_{2}}\right) .
$$

Using the values from that paper, $\eta_{1}=2.1$ and $\eta_{2}=-0.3$, there are increasing marginal costs of posting vacancies, which generates transition dynamics at the level of the firm. The convexity is not very strong, and consequently convergence in the model is relatively fast: depending on its size, a firm reaches more than $50 \%$ of its steady state employment stock within 3-4 years, and more than 90\% in 8-10 years. Nevertheless, these size differences are an important source of within-group inequality. In order to grow fast, young firms offer higher wages than older firms that only need to do replacement hiring. The scale parameter is chosen to match the average unemployment rate of $7.2 \%$ in 1980 . The fraction of high-skilled workers in the labor force is set to $26.5 \%$; i.e., $\bar{h}=0.265$, which is slightly less than their employment share to ensure a lower unemployment rate for high-skilled workers. The parameters are listed in Table 1.

\subsection{Results}

The results for the 1980 equilibrium are summarized in Table 2. In line with Hornstein et al. (2010), the within-group dispersion generated by the model is small. ${ }^{12}$ As in Kaas and Kircher (2015), young firms wish to grow quickly and offer higher wages; their high offers generate the noticeable long tail of the wage distribution. However, although the model fails to deliver the level of residual inequality found in the data, qualitatively the predictions are in line with the data-controlling for age, both larger and faster-growing firms pay higher wages. Consequently, I evaluate the model's prediction for the link between trade and inequality relative to the 1980 equilibrium.

After computing the 1980 equilibrium, I increase trade by increasing the foreign demand for U.S. products between 1980 and 2005. The increase in trade is biased in favor of the $\mathrm{H}$-industries, which see an average 5.7-percentage-point increase in exports as a fraction of total sales, whereas for L-industries the increase is only 2.6 percentage points on the average. ${ }^{13}$ Moreover, imports are slightly biased against the L-industries as well, in that the ratio of $\mathrm{H}$-competing to L-competing imports in 2005 is 0.96 . Second, I compute the counterfactual experiment in which the 
TABLE 1. Parameter selection

\begin{tabular}{lcl}
\hline Parameter & Value & \\
\hline$\sigma$ & 0.25 & $\begin{array}{l}\text { Elasticity of substitution between skilled and } \\
\text { unskilled labor }=1.33 \\
\end{array}$ \\
$\varphi$ & 0.75 & $\begin{array}{l}\text { Elasticity of substitution between varieties }=4 \\
\text { Expenditures shares for }(\mathrm{H}, \mathrm{L}) \text { industries }\end{array}$ \\
$\zeta$ & {$[0.487,0.513]$} & Firm exit rate \\
$\gamma_{h}$ & 0.1 & High skill worker separation rate \\
$\gamma_{u}$ & 0.1 & Low skill worker separation rate \\
$\lambda_{u}$ & 0.15 & Weight on $u$ workers in production in $(\mathrm{H}, \mathrm{L})$ industries \\
$\eta_{1}$ & {$[0.602,0.715]$} & Curvature of vacancy cost function \\
$\eta_{2}$ & 2.1 & from Cosar et al. (in press) \\
$\alpha$ & -0.3 & Elasticity of matching function \\
$\bar{h}$ & 1.27 & Fraction of high skilled workers in the labor force \\
$f^{e}$ & 0.265 & Entry cost \\
$f^{p}$ & 1 & Trade cost \\
$\tau_{m}, \tau_{x}$ & 0.285 & Iceberg cost \\
$\beta$ & 1.3 & Discount factor \\
\hline
\end{tabular}

TABLE 2. Results

\begin{tabular}{lllc}
\hline & 1980 & 2005 & Counterfactual \\
\hline Unemployment rate $h$-skilled & 4.54 & 2.55 & 5.11 \\
Unemployment rate $u$-skilled & 8.16 & 7.96 & 7.85 \\
Skill premium & 0.338 & 0.377 & 0.337 \\
Std. dev. $\log \left(w_{h}\right)$ & 0.0163 & 0.0165 & 0.0168 \\
Std. dev. $\log \left(w_{u}\right)$ & 0.0175 & 0.0181 & 0.0177 \\
Gains from trade $(\% \Delta \mathbf{Q})$ & & 1.56 & 2.97 \\
$\Delta$ 90-50 log wage gap (overall) & & 0.040 & 0.005 \\
$\% \Delta$ 90-50 residual log wage gap & & -0.41 & -0.37 \\
$\% \Delta$ 50-10 residual log wage gap & & -1.12 & -0.04 \\
$\% \Delta$ 99-10 residual log wage gap & & 0.17 & -0.36 \\
$\% \Delta$ Theil index $h$-skilled & & -8.0 & 4.0 \\
$\% \Delta$ Theil index $u$-skilled & & 6.0 & 1.0 \\
\hline
\end{tabular}

skill bias of trade is reversed. This counterfactual experiment is meant to show to what extent the labor market effects of increased trade are invariant to the skill bias of trade and to what extent they are ultimately an empirical matter.

Actual U.S. trade experience. Output of the final consumption good increases by $1.6 \%$ in actual U.S. trade experience and, because of the strong incentive for the most productive firms to hire additional workers, unemployment among high-skilled workers decreases noticeably, from $4.5 \%$ to $2.6 \%$. Unemployment 
among low-skilled workers remains almost constant, falling from $8.2 \%$ to $8.0 \%$. The skill premium increases by $3.8 \log$ points, which is about one-seventh of the observed increase in the skill premium over that time period. ${ }^{14}$ It is also worth noting that because of the increase in the skill premium, the model predicts a 4 log point increase in the 90-50 inequality in the overall wage distribution. The change in within-group (residual) inequality is minor and its sign depends on the measure used. Measures that are not sensitive to outliers, such as the 90-10 and 90-50 residual log wage differentials, decrease slightly. However, the Theil index [Helpman et al. (2010)] shows a small increase in within-group inequality for low-skilled workers and a decrease for high-skilled workers.

To understand these results, notice that there are two forces at play: the skill bias of exporting that stems from the interplay of heterogeneous firms and the skillbiased technology, and the industry composition effect. The industry composition effect arises because employment in the exporting industry grows, while employment in the importing industry shrinks. This benefits the worker type that is more intensively employed in the exporting industry-the Stolper-Samuelson effect. At the same time, within an industry the demand for high-skilled workers increases because only the most productive firms with the highest skill intensity export. If, as in the U.S. experience, the exporting industry is high-skill-intensive, the two effects work in the same direction and the skill premium increases significantly.

Employment at the larger, more productive firms increases and it shrinks at the smaller, less productive firms. This decreases the lower-tail (50-10) and upper tail (90-50) residual wage gaps, while slightly increasing the residual wage gap at the top of the distribution (99-90). However, the Theil index, which is separately computed for each group and more sensitive to outliers, indicates that inequality has slightly increased for low-skilled workers. Low-skilled workers are now more dispersed across firm productivities. Similarly, for high-skilled workerswho were already more likely to be employed by high-productivity firms — wage dispersion has decreased.

Unemployment falls more for high-skilled workers than for low-skilled workers, as the growing firms employ relatively more high-skilled workers and the shrinking firms employ relatively more low-skilled workers. However, because firms can increase their employment by increasing the number of vacancies or the yield per vacancy, the drop in unemployment is not obvious. Because the vacancy function is not very convex, firms increase their labor force more through additional vacancies, and unemployment falls. This also explains why the increase in withingroup inequality is not larger-if the marginal cost of an additional vacancy were more strongly increasing, unemployment would fall less (or even increase) and within-group inequality would increase more strongly.

It is important to note that the magnitude of the gains from trade and the change in the skill premium represent an upper bound. The calibrated model matches the U.S. manufacturing sector, which represented about $20 \%$ of total jobs in 1980 . This amplifies the effect of trade relative to the total size of the economy and hence its effect on the gains from trade and the skill premium. 
Counterfactual trade experience. Although the model predicts a relatively small reallocation of workers across industries in the preceding simulation $(\mathrm{H}$ industries grow from $51.4 \%$ to $54.6 \%$ of total manufacturing employment), this across-industry reallocation nevertheless increases the skill premium. To gauge its importance relative to the within-industry reallocation effect, I reverse the trade pattern and assume that the United States has a comparative advantage in the low-skill-intensive industries.

In this case, the model predicts that the skill premium would have fallen by $0.1 \mathrm{log}$ points. However, in order to match the trade flows, a larger reallocation of workers toward the $\mathrm{L}$ industries is needed; in this scenario, $\mathrm{H}$ industries only employ $46.6 \%$ of all manufacturing employment. In line with the small decrease in the skill premium, the counterfactual experience predicts a $0.5 \log$ point decrease in the 90-50 inequality in the overall wage distribution. All quantile measures of the residual wage gap show small decreases, whereas the Theil index for both skill groups indicates a small increase in within-group inequality.

\section{CONCLUSION}

This paper embeds a competitive search model of the labor market into a small open economy with firm and worker heterogeneity. In addition to the presence of income differences between skill groups, search frictions generate equilibrium unemployment and income inequality between identical workers in a parsimonious way. The model therefore incorporates multiple channels through which increased trade might affect the labor market. Using the model for a quantitative assessment of the U.S. trade experience demonstrates that although it seems likely that the U.S. trade experience contributed to the increase in the skill premium over the past 30 years, the contribution of trade to income inequality was likely minor.

\section{NOTES}

1. Harrison et al. (2011) provide an extensive survey of its various facets.

2. King and Stähler (2014) embed a directed search model into a general equilibrium trade model to study the effect of trade on unemployment, but do not address the question of inequality.

3. Helpman and Itskhoki (2010) present a search model with large firms, but focus on an equilibrium without wage dispersion. They find that unemployment may fall or rise depending on the country's labor market frictions relative to those of its trading partner.

4. An additional difference between the random search models in Helpman et al. (2010) and Cosar et al. (in press) and the competitive search model in this paper is that the competitive search equilibrium is constrained efficient because of the firms' commitment to long-term contracts.

5. The assumption of flat wages is made for convenience. The competitive search framework pins down the total expected payments over the course of the employment relationship, but not a specific time path of wages. However, in a world with risk-averse workers, firms would offer flat wages in a stationary equilibrium, so this assumption is not unnatural. Alternatively, firms could pay workers varying sign-on bonuses and subsequently their reservation wages, as in Kaas and Kircher (2015).

6. To simplify notation, I will suppress the industry index $j$ if there is no risk of confusion.

7. Estimates for the elasticity of substitution between skilled and unskilled labor lie in the range 1002. This contrasts with estimates of 2-10 for the elasticity of substitution between varieties. 
8. See, for example, Helpman et al. (2010) and Cosar et al. (in press); a detailed discussion of the role of commitment to future payments (though not necessarily fixed wages) can be found in Hawkins (2015).

9. U.S. trade data made available by the NBER, based on Schott (2008).

10. Broda and Weinstein (2006) find an elasticity between 3 and 4, depending on the level of aggregation. Cosar et al. (in press) estimate the elasticity to be 6.8 .

11. In the model, the variable cost of exporting, $\tau_{x}$, and the demand shifter, $A_{\mathrm{X}}$, are not separately identified. I therefore use the demand shifters to match the trade flows and set both iceberg costs to $30 \%$; i.e., $\tau_{x}=\tau_{m}=1.3$.

12. Adding on-the-job search could potentially increase the level of wage dispersion to a level more in line with the data. Unfortunately, adding on-the-job search increases the computational difficulty greatly, as the distribution of wages paid within a firm becomes a state variable in the firm's problem (i.e., the quit rates depend on the wages paid).

13. U.S. trade data made available by the NBER, based on Schott (2008).

14. The college/high-school wage gap rose by about $25 \log$ points from the late 1970s/early 1980s to the mid-2000s [Goldin and Katz (2007); Acemoglu and Autor (2010)].

\section{REFERENCES}

Acemoglu, Daron and David Autor (2010) Skills, tasks and technologies: Implications for employment and earnings. In Orley Ashenfelter and David Card (eds.), Handbook of Labor Economics, Vol. 4, Part B, pp. 1043-1171. Amsterdam: Elsevier North Holland.

Bernard, Andrew, J. Bradford Jensen, Stephen Redding, and Peter Schott (2007) Firms in international trade. Journal of Economic Perspectives 21(3), 105-130.

Bernard, Andrew, J. Bradford Jensen, Stephen Redding, and Peter Schott (2012) The empirics of firm heterogeneity and international trade. Annual Review of Economics 4, 283-313.

Broda, Christian and David E. Weinstein (2006) Globalization and the gains from variety. Quarterly Journal of Economics 121(2), 541-585.

Burstein, Ariel and Jonathan Vogel (2012) International Trade, Technology, and the Skill Premium. Working paper, Columbia University.

Cosar, Kerem, Nezih Guner, and James Tybout (in press) Firm dynamics, job turnover, and wage distributions in an open economy. American Economic Review.

Costinot, Arnaud and Jonathan Vogel (2010) Matching and inequality in the world economy. Journal of Political Economy 118(4), 747-786.

Davidson, Carl, Steven Matusz, and Andrei Shevchenko (2008a) Globalization and firm-level adjustment with imperfect labor markets. Journal of International Economics 75(2), 295-309.

Davidson, Carl, Steven Matusz, and Andrei Shevchenko (2008b) Outsourcing Peter to pay Paul: Highskill expectations and low-skill wages with imperfect labor markets. Macroeconomic Dynamics 12, 463-479.

Davis, Donald and James Harrigan (2011) Good jobs, bad jobs, and trade liberalization. Journal of International Economics 84(1), 26-36.

Den Haan, Wouter J., Garey Ramey, and Joel Watson (2000) Job destruction and propagation of shocks. American Economic Review 90(3), 482-498.

Egger, Harmut and Udo Kreickemeier (2009) Firm heterogeneity and the labour market effects of trade liberalization. International Economic Review 50(1), 187-216.

Epifani, Paolo and Gino Gancia (2008) The skill bias of world trade. Economic Journal 118(530), 927-960.

Goldberg, Penny and Nina Pavcnik (2007) Distributional effects of globalization in developing countries. Journal of Economic Literature 45(1), 39-82.

Goldin, Claudia and Lawrence F. Katz (2007) Long-run changes in the U.S. wage structure: Narrowing, widening, polarizing. Brookings Papers on Economic Activity 38, 135-168. 
Harrigan, James and Ariell Reshef (in press) Skill biased heterogeneous firms, trade liberalization, and the skill premium. Canadian Journal of Economics 48(3).

Harrison, Ann, John McLaren, and Margaret S. McMillan (2011) Recent perspectives on trade and inequality. Annual Review of Economics 3, 261-289.

Hawkins, William (2015) Bargaining with commitment between workers and large firms. Review of Economic Dynamics 18(2), 350-364.

Helpman, Elhanan and Oleg Itskhoki (2010) Labour market rigidities, trade and unemployment. Review of Economic Studies 77(3), 1100-1137.

Helpman, Elhanan, Oleg Itskhoki, and Stephen J. Redding (2010) Inequality and unemployment in a global economy. Econometrica 78(4), 1239-1283.

Hornstein, Andreas, Per Krusell, and Giovanni L. Violante (2010) Frictional wage dispersion in search models: A quantitative assessment. American Economic Review 101(7), 28732898.

Kaas, Leo and Philipp Kircher (2015) Efficient firm dynamics in a frictional labor market. American Economic Review 105(10), 3030-3060.

Katz, Lawrence F. and Murphy, Kevin M. (1992) Changes in relative wages, 1963-1987: Supply and demand factors. Quarterly Journal of Economics 107(1), 35-78.

King, Ian and Frank Stähler (2014) A simple theory of trade and unemployment in general equilibrium. Canadian Journal of Economics 47(2), 580-604.

Krugman, Paul (1979) Increasing returns, monopolistic competition and international trade. Journal of International Economics 9(4), 469-479.

Krusell, Per, Lee E. Ohanian, José-Víctor Ríos-Rull, and Giovanni L. Violante (2000) Capitalskill complementarity and inequality: A macroeconomic analysis. Econometrica 68(5), 10291053.

Melitz, Marc (2003) The impact of trade on intra-industry reallocations and aggregate industry productivity. Econometrica 71(6), 1695-1725.

Molina, Danielken and Marc-Andreas Muendler (2013) Preparing to Export. NBER working paper 18962.

Ritter, Moritz (in press) Trade and inequality in a directed search model with firm and worker heterogeneity. Canadian Journal of Economics 48(5).

Sampson, Thomas (2014) Selection into trade and wage inequality. AEJ: Microeconomics 6(3), 157-202.

Schott, Peter (2008) The relative sophistication of Chinese exports. Economic Policy 23(1), 549.

Yeaple, Stephen Ross (2005) A simple model of firm heterogeneity, international trade, and wages. Journal of International Economics 65(1), 1-20.

\section{APPENDIX: OPEN ECONOMY EQUILIBRIUM}

The stationary equilibrium can be computed using the following conditions:

- Searching workers indifferent between all active submarkets, (3).

- The firms' hiring decisions satisfy (11) and (12).

- Zero expected profits for newly entering firms in each industry, (16).

- Invariant distribution of firms across industries, productivity levels, and ages, (17).

- Aggregate resource feasibility (labor market clearing).

- Market clearing for all industries.

- Balanced trade. 


\section{A.1. LABOR MARKET CLEARING}

Total supply of high- and low-skilled workers is $\bar{h}$ and $(1-\bar{h})$, respectively. Workers can be either employed or unemployed. Summing over all firms in all industries, labor market clearing requires

$$
\begin{aligned}
(1-\bar{h}) & =\sum_{j=1}^{J} \sum_{a \geq 0} \int_{s}\left[u(s, a)+g^{V_{u}}(s, t) g^{\theta_{u}}(s, t)\right] f(s, a, j) d s+N^{\mathrm{F}}, \\
\bar{h} & =\sum_{j=1}^{J} \sum_{a \geq 0} \int_{s}\left[h(s, a)+g^{V_{h}}(s, t) g^{\theta_{h}}(s, t)\right] f(s, a, j) d s .
\end{aligned}
$$

\section{A.2. GOODS MARKET CLEARING}

Aggregate income in the economy is given by

$$
\mathbf{Y}=\sum_{j=1}^{J} \sum_{a \geq 0} \int_{s} W(j, s, a) f(s, a, j) d s+\bar{\Pi},
$$

where

$$
\begin{aligned}
& W(s, a, j)=\sum_{t=0}^{a-1} w_{u}\left(g^{\theta_{u}}(s, t, j)\right) g^{V_{u}}(s, t, j) m\left(g^{\theta_{u}}(s, t, j)\right)(1-\gamma)^{a-t-1} \\
& +\sum_{t=0}^{a-1} w_{h}\left(g^{\theta_{h}}(s, t, j)\right) g^{V_{h}}(s, t, j) m\left(g^{\theta_{h}}(s, t, j)\right)(1-\gamma)^{a-t-1},
\end{aligned}
$$

and

$$
w_{i}\left(\theta_{i}\right)=(1-\beta) \mathcal{U}_{i}+\frac{\theta_{i}}{m\left(\theta_{i}\right)} \frac{[1-\beta(1-\pi)]}{(1-\delta)} \overline{\mathcal{W}}_{i}
$$

denotes wages paid out to workers (hired in different periods) by firm $(s, a, j)$ and

$$
\bar{\Pi}=\sum_{j=1}^{J} \sum_{a \geq 0} \int_{s} \Pi(j, s, a) f(s, a, j) d s-\sum_{j=1}^{J} N_{0}(j) f_{e},
$$

where

$\Pi(s, a, j)=A\left(\mathbf{I}_{x}\right) \bar{a}\left[\lambda_{u} u^{\rho}+\left(1-\lambda_{u}\right)(s h)^{\rho}\right]^{\frac{\varphi}{\rho}}-W(s, a, j)-C_{u}\left(V_{u}, u\right)-C_{h}\left(V_{h}, h\right)-\mathbf{I}_{x} f_{x}$

is the total profits of all firms.

Market clearing requires demand to equal domestic supply plus imports,

$$
\frac{\zeta_{j} \mathbf{Y}}{P_{j}}=\left[\sum_{a \geq 0} \int_{s}\left[\frac{y(s, a, j)}{B_{\mathrm{H}}(j)}\right]^{\varphi} f(s, a, j) d s\right]^{1 / \varphi}+A_{j}\left(\tau_{m} e\right)^{\frac{-\varphi}{1-\varphi}}
$$

where $B_{\mathrm{H}}(j)=\left(1+\frac{A(j)_{\mathrm{X}}}{A(j)_{\mathrm{H}}} \tau_{m}^{\varphi /(\varphi-1)} e^{1 /(1-\varphi)}\right)$. 
Demand for services comes from firms that pay their fixed costs and recruiting costs:

$$
\begin{aligned}
N^{\mathrm{F}} & =\sum_{j=1}^{J}\left[N_{0}(j) f_{e}+f_{x} \sum_{a \geq 0} \int_{s} \mathbf{I}_{x}(s, a, j) f(s, a, j) d s\right] \\
& +\sum_{j=1}^{J} \sum_{a \geq 0} \int_{s}\left[C_{u}\left(g^{V_{u}}(s, t), u(s, a)\right)+C_{\mathrm{H}}\left(g^{V_{h}}(s, t), h(s, a)\right)\right] f(s, a, j) d s .
\end{aligned}
$$

\section{A.3. TRADE BALANCE}

The demand function for each variety is given by

$$
y(j, k)=A_{j} p(j, k)^{\frac{-1}{1-\varphi}} .
$$

A subset $K_{j}^{\mathrm{F}}$ of differentiated goods in industry $j \in J$ are imported from the rest of the world. Their prices are exogenous to the economy, so one can normalize the world market price of the imported bundle:

$$
\left[\int_{k \in K_{j}^{\mathrm{F}}} p(j, k)^{\frac{-\varphi}{1-\varphi}}\right]^{\frac{\varphi-1}{\varphi}}=1 .
$$

Thus, the domestic price for the imported bundle $P^{\mathrm{F}}=\tau_{m} e$, where $\left(\tau_{m}-1\right)>0$ denotes the iceberg cost of imported goods and $e$ denotes the exchange rate. This normalization also determines the comparative advantage of the economy. Although there will be trade in all tradable industries, there will be more in some than in others, depending on the autarky relative price between industries. The price index for the differentiated good in the small open economy can then be written

$$
P(j)=\left[\int_{k \in K_{j}^{\mathrm{D}}} p(j, k)^{\frac{-\varphi}{1-\varphi}}+\left(\tau_{m} e\right)^{\frac{-\varphi}{1-\varphi}}\right]^{\frac{\varphi-1}{\varphi}},
$$

and the demand for domestic and imported varieties is given by

$$
y^{\mathrm{D}}(j, k)=A_{j} p(j, k)^{\frac{-1}{1-\varphi}}
$$

and

$$
y^{\mathrm{F}}(j, k)=A_{j}\left[\tau_{m} e p(j, k)\right]^{\frac{-1}{1-\varphi}},
$$

respectively.

The total expenditure on foreign goods in domestic currency is given by

$$
\begin{aligned}
E_{\mathrm{F}} & =\sum_{j=1}^{J} \int_{K_{j}^{\mathrm{F}}} \tau_{m} e p(j, k) y^{\mathrm{F}}(j, k) \\
& =\sum_{j=1}^{J} A_{j}\left(\tau_{m} e\right)^{\frac{-\varphi}{1-\varphi}},
\end{aligned}
$$


where the second line uses the normalization of the foreign price level in each industry. Total export revenues are

$$
R_{\mathrm{X}}=\sum_{j=1}^{J} \sum_{a \geq 0} \int_{s} e\left[\frac{y(s, a, j)}{\tau_{x}}\right]^{\varphi} A(j)_{\mathrm{X}}^{1-\varphi}\left(\frac{1}{B_{\mathrm{X}}}\right)^{\varphi} \mathbf{I}_{x}(j, s, a) f(s, a, j) d s,
$$

where $B_{\mathrm{X}}=1+\frac{A(j)_{\mathrm{H}}}{A(j)_{\mathrm{X}}} \tau_{m}^{\varphi /(1-\varphi)} e^{1 /(\varphi-1)}$.

Finally, balanced trade requires that

$$
R_{\mathrm{X}}=E_{\mathrm{F}}
$$

